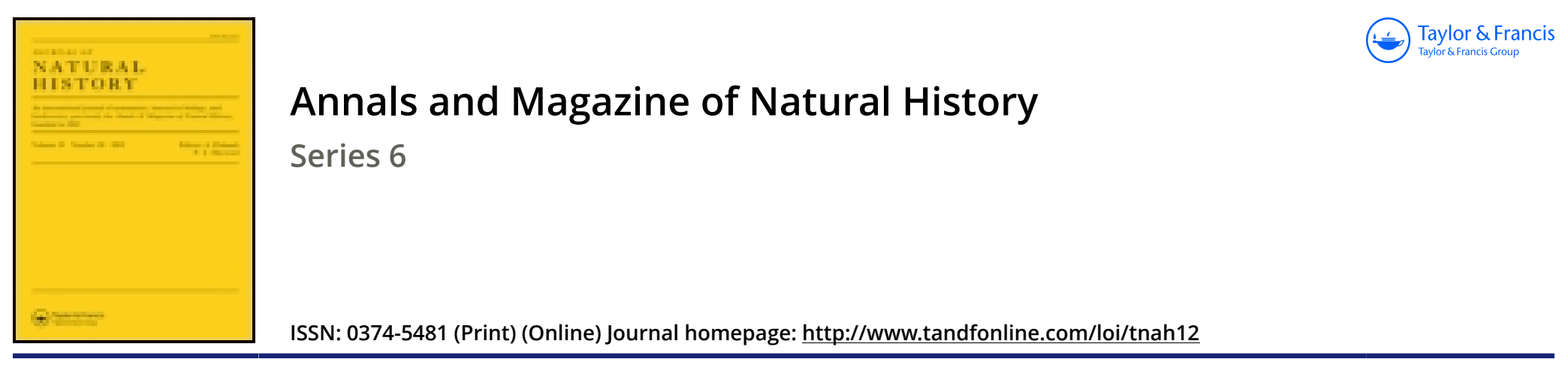

\title{
LVII.-Description of a new species of Scolopendra from the Solomon Islands
}

\section{R.I. Pocock}

To cite this article: R.I. Pocock (1895) LVII.-Description of a new species of Scolopendra from the Solomon Islands, Annals and Magazine of Natural History, 16:95, 423-424, DOI: 10.1080/00222939508680296

To link to this article: http://dx.doi.org/10.1080/00222939508680296

冓 Published online: 06 Oct 2009.

Submit your article to this journal $\lceil\pi$

Џ Article views: 3

Q View related articles $₫$ 
and the last-named extending all along the shores of the Mediterranean as far as Suez. Mimosella gracilis is only found on the shores of Devon and Cornwall.

According to Mr. Gosse (6), Anthea cereus is found at Madeira.

I think the foregoing examples are sufficient to demonstrate clearly that seaweeds, and particularly those furnished with air-vessels, have played in the past, as they continue to do at present, a most important part in the dispersal of many of our littoral forms over the globe.

\section{References.}

(1) Watlace, Alfred R.-The Geographical Distribution of Animals, London, 1876 .

(2) Sollas, W. J.-On the Origin of Freshwater Faunas: a Study in Evolution. Sci. Trans. Royal Dublin Society, vol, ii. (ser. ii.) part 5. Nov. 1884.

(3) Forbes, E., and Hanley, S.-A History of British Mollusca and their Skells.

(4) Hincis, 'THomas.-A History of British Hydroid Zoophytes.

(5) Hincks, Thomas.-A History of British Marine Polyzoa.

(6) Gosse.-A History of British Sea-Anemones and Corals.

LVII.-Description of a new Species of Scolopendra from the Solomon Islands. By R. I. Pocock.

Scolopendra metuenda, sp. n.

Colour. The terga a deep olive-chestnut, head nearly black; antennæ, legs, and sterna rather greener than the terga; at the posterior end of the budy the chestnut colour predominates on the somites.

Head without sulci, finely punctured, a little wider than long.

Antenno long and slender, composed of 19 or 20 long cylindrical segments, whereof the basal five are smooth, though punctured, and the rest pubescent.

Maxillipedes finely punctured, the precoxal plates very short, but wide, with convex distal edges, each furnished with upwards of a dozen or more small, in parts nearly obsolete, teeth, which present the appearance of having been worn away; the femoral process simple, small, and curved back against the appendage.

T'ergites. First without either longitudinal or transverse sulci; on the rest the longitudinal sulci start upon the third and extend to the twentieth, but are everywhere faint (except upon the extreme anterior and posterior edges of the terga), and almost die out in the middle of the body; a faint shallow median longitudinal furrow upon the terga. The lateral margin from the third to the twentyfirst elevated.

Sternites smooth and shining, weakly bisulcate.

Anal somite small; tergite not mesially sulcate, its width equal to the length of its lateral margin, but a little less than its median 
length; pleuro densely porous, terminating in a blunt process, which is tipped with 4 or 5 small spines; sternite long and narrow, posteriorly attenuate, with truncate hinder edge, its basal width about two thirds of its length ; legs long and slender, nearly four times the length of the head, the segments cylindrical and about four times as long as wide; femora armed with about 14 small spines, 3, 3, 2 in three longitudinal rows on the inner surface and 3,3 in two rows on the external half of the lower surface; the femoral process armed with from 4 to 10 small spines; no tarsal spur, claws basally spurred.

The rest of the legs long and slender, with a tarsal spur.

Measurements in millimetres. - Total length 163 , of antenna 37, of anal leg 41 ; width of head 10.5 , length 10 ; width of twelfth tergite 14 , of twenty-first 8 .

Loc. New Georgia (Solomon Islands).

A couple of specimens of this species were obtained by Commander Barker, R.N., of H.M.S. 'Penguin.' The second specimen is a little smaller than the type, being 145 millim. long, and much more uniformly chestnut in colour.

In its general features this handsome new species presents considerable resemblance to the cosmopolitan S. subspinipes of Leach, out may be at once recognized by the spine-armature of its anal legs, the former species having only two or three spines on tho lower surface of the anal femora and only three or four on the inner surface. It also has but five or six teeth on the precoxal plates of the maxillipedes, whereas in $S$. metuendr there are a large number of minute more or less obsolete teeth on these plates. In this respect S. metuenda would seem to approach S. polyodonta, Daday (Term. füzetek, xvi. p. 109 , pl. v. fig. $7 \&$ \&), from New Guinea; but the latter has the anal femora unarmed, as in the variety of $S$. de Haanii named inermis by Newport.

MISCELLANEOUS.

On the Status of the Names Aplysia and Tethys. By Henry A. Pilsbry.

Is the course of my studies on the "Sea-Hares," preliminary to the preparation of a monograph of this group of tectibranch mollusks for the 'Manual of Conchology,' my attention was early forced to the fact that in Linneus's tenth edition of the 'Systema Naturæ' the genus Tethys was proposed for the animal now known as Aplysia, and included nothing else. Moreover, by the terms of the generic diagnosis, such creatures as that known as Tethys in modern times are excluded.

In the twelfth edition of the 'Systema' Tethys is given a completely different meaning, and the new term Aplysia (Laplysia) is brought forward to include the species of the earlier Tethys. This later usage has been accepted by zoologists until the present day. 